Print ISSN: 2502-1397 / Online ISSN 2540-8100

https://doi.org/10.32505/j-ebis.v6i1.2605

\title{
COMPARISON OF VILLAGE DEVELOPMENT BEFORE AND AFTER VILLAGE FUND IMPLEMENTATION IN NAGAN RAYA DISTRICT
}

\author{
Arroyyan Ramly \\ STAIN Teungku Dirundeng Meulaboh, arroyyanramly@ staindirundeng.ac.id
}

\begin{abstract}
This study aims to analyze and see the effectiveness of the distribution of the use of village funds in Kuala Subdistrict, Nagan Raya Regency and its relationship with poverty levels. The data used is in the form of time series data from 2015 to 2018 which is collected through primary and secondary data. Primary data were obtained by directly visiting villages in the Kuala sub-district. Meanwhile, secondary data were obtained from the website of the Central Statistics Agency (BPS), document review, articles related to the object of research. This study conducted observations of 10 villages as a sample of 17 villages in Kuala District. The analysis method uses panel data regression with the random effect model (REM) analysis method. From the regression results of the random effect model, it was found that the village fund variable had a positive and significant effect on poverty with a probability of $0.0000=$ p-value $\alpha=5 \%$. Then the village fund allocation variable has a significant negative effect on poverty with a probability of $0.0000=$ p-value $\alpha=5 \%$. This means that adding $1 \%$ of village funds or increasing village funds will reduce poverty in Kuala Subdistrict, Nagan Raya Regency.
\end{abstract}

Keywords: Comparison, Village Fund, Poverty.

\begin{abstract}
Abstrak
Penelitian ini bertujuan menganalisa dan melihat efektifitas distribusi pemanfaatan dana desa di Kecamatan Kuala Kabupaten Nagan Raya dan hubungannya dengan tingkat kemiskinan. Data yang digunakan berupa data time series dari tahun 2015 hingga tahun 2018 yang dikumpulkan melalui data primer dan sekunder. Data primer diperoleh dengan mendatangi langsung ke desa-desa di kecamatan kuala. Sementara data sekunder diperoleh dari website Badan Pusat Statistik (BPS), telaah dokumen, artikel yang berhubungan dengan objek penelitian. Penelitian ini melakukan observasi terhadap 10 desa sebagai sample dari 17 desa di Kecamatan Kuala. Metode analisa mengunakan regresi data panel dengan metode analisa random effect model (REM). Dari hasil regresi model random effect ditemukan bahwa variabel dana desa berpengaruh positif dan signifikan terhadap kemisikinan dengan Probabilitas sebesar $0,0000=p$-value $\alpha=5 \%$. Kemudian variabel alokasi dana desa berpengaruh negatif signifikan terhadap kemiskinan dengan Probabilitas sebesar $0,0000=p$-value $\alpha=5 \%$. Artinya dengan menambahkan $1 \%$ dana desa atau meningkatkan dana desa akan mengurangi kemiskinan di Kecamatan Kuala Kabupaten Nagan Raya.
\end{abstract}

Kata kunci: Perbandingan, Dana Desa, Kemiskinan. 
Arroyyan Ramly: Comparison of Village Development Before and After Village Fund

\section{PENDAHULUAN}

Berdasarkan Undang-Undang Nomor 6 Tahun 2014 tentang Desa, mengatur tentang Implementasi penggunaan Dana Desa dalam hal Perencanaan, Penganggaran, Pelaksanaan, Pengadaan Barang dan Jasa, Pelaporan, Pembinaan serta Pengawasan. Undang-Undang ini memberikan peluang besar dalam meningkatkan ekonomi dan kesejahteraan masyarakat, khususnya di wilayah perdesaan. Setiap desa di Indonesia memiliki kewenangan dan kesempatan lebih luas untuk merumuskan kebijakan dan melaksanakan pembangunannya sendiri sehingga desa menjadi subjek yang berperan aktif sebagai motor penggerak pembangunan.

Pemerintah desa diharapkan secara mandiri mengelola pemerintahan dengan sumber daya yang dimilikinya, termasuk di dalamnya pengelolaan keuangan dan kekayaan milik desa. Oleh karena itu pemerintah desa harus bisa menerapkan prinsip transparansi dan akuntabilitas dalam tata pemerintahannya, di mana semua akhir kegiatan penyelenggaraan pemerintahan desa harus dapat dipertanggungjawabkan kepada masyarakat desa sesuai dengan ketentuan (BPKP, 2015).

Tujuan pembangunan desa adalah meningkatkan kesejahteraan hidup manusia serta penanggulangan kemiskinan melalui penyediaan pemenuhan kebutuhan dasar, pembangunan sarana dan prasarana desa, pengembangan potensi ekonomi lokal dan pemanfaatan sumber daya alam dan lingkungan secara berkelanjutan. Pembangunan desa dilaksanakan dengan mengedepankan semangat kebersamaan, kekeluargaan, dan kegotongroyongan guna mewujudkan pengarusutamaan perdamaian serta keadilan sosial.

Secara intensif dan efektif Dana Desa akan mendorong peningkatan taraf hidup dan kesejahteraan masyarakat dengan menitik beratkan pada Pembangunan pedesaan sebagai sasaran pembangunan (Tangkumahat,dkk, 2017), guna untuk meningkatnya pemerataan pendapatan, kesempatan kerja dan kesempatan berusaha bagi masyarakat desa dalam rangka pengembangan sosial ekonomi masyarakat juga mengurangi berbagai kesenjangan desa dan kota dan peningkatan perekonomian di Desa, Tidak terkecuali di kecamatan kuala Kabupaten nagan raya.

Kecamatan kuala merupakan salah satu kecamatan di Kabupaten Nagan raya yang merupakan kabupaten hasil pemekaran dari kabupaten Aceh Barat. 
Luas wilayah 3.544.90 hektar dengan potensi yang hutan, laut, perkebunan, dan tambang dengan pertumbuhan ekonomi 3.89 persen di Tahun 2015. Namun prosenstase penduduk miskin di Kabutapen Nagan Raya masih tinggi sekitar 20,13 persen pada tahun 2015, persentase ini lebih baik dibandingkan tahun sebelumnya dengan persentase 24 hingga 33 persen jumlah penduduk miskin dan 19.25 persen pada Tahun2017.

Kecamatan kuala memiliki 17 desa yang masing-masingnya memiliki wilayah strategis dan sangat berpotensi untuk pendongkrak perekonomian masyarakat, Kecamatan kuala merupakan sentral akses bagi masyarakat dengan garis wilayah yang menghubungkan antar kabupaten di Provinsi Aceh. selain itu posisi kecamatan kuala memiliki akses terhadap pasar induk dan pusat pelayanan publik seperti perkantoran, dan rumah sakit daerah. Sedangkan distribusi luas Kecamatan Kuala sebesar 3.41 persen dari luas Kabupaten Nagan Raya. Namun masih terdapat masyarakat yang berada di bawah garis kemiskinan yang tidak memiliki akses terhadap pemanfataan pembangunan desa di Kecamatan Kuala. Oleh karena itu sesuai dengan tujuan pemerintah mengalokasikan dana desa untuk meningkatkan pemerataan ekonomi dan meningkat kesejahteraan masyarakat melalui program alokasi dana desa dan alokasi dana gampong di Kecamatan Kuala demi terwujudnya desa yang mandiri melalui implementasi kebijakan dana desa dan konstribusi Badan Usaha Milik Gampong (BUMG) yang ada di kecamatan kuala.

Dana Desa sebetulnya memiliki potensi sangat besar dalam upaya mempercepat pertumbuhan dan pembangunan Desa dalam mengatasi berbagai persoalan yang selama ini ada. Namun bagaimana menjaga supaya pemanfaatan tersebut tetap di koridor yang diharapkan? jumlah anggaran yang meningkat sehingga desa dituntut dapat mengembangkan kualitas dan kesejahteraan masyarakatnya. Kesejahteraan masyarakat desa tentu menjadi input yang bermanfaat baik bagi desa itu sendiri maupun bagi daerah lainnya. Desa yang maju ditunjang oleh perkembangan perekonomian yang seimbang seperti wilayah di perkotaan. seperti halnya penelitian yang pernah dilakukan oleh azwardi \& Sukanto (2014), Sari dan Abdullah (2017), dan Tangkumahat,dkk (2017), melakukan penelitian terhadap efektivitas alokasi dana desa terhadap kemiskinan, penelitian ini menunjukkan pengaruh negatif terhadap kemiskinan. (Azwardi \& 
Sukanto, 2014). Kemudian Sari dan Abdullah (2017), mengukapkan hasil penelitiannya, bahwasanya dengan adanya alokasi dana desa berpengaruh terhadap kemiskinan sebesar -4.52 dan -1.52 masing-masing sesuai variabel. artinya denga adanya ADD tingkat kemiskinan di kabupaten tulungagung, kemudian penelitian tangkumahat, dkk (2017), menunjukkan hasil bahwasanya program dana desa berjalan baik, dan perlu ada peningkatan pelaksanaan dalam menjalankan program dana desa. kemudian penelitian yang dilakukan Ramly, dkk (2018), menunjukkan hasil peningkatan perekonomian di desa meningkat dengan memanfaatkan potensi desa yang ada sehingga dapat menekan angka kemiskinan dan mensejahterakan masyarakat.

namun dalam beberapa penelitian di atas seperti Sari dan Abdullah (2017) dan Azwardi \& Sukanto, (2014). memiliki indikator yang berbeda dan jumlah variabel data terbatas hanya 10 responden, sedangkan penelitian ini menggunakan sumber data 10 desa dan menggunakan metode regresi data panel. dari sampel 10 desa yang diambil ada beberapa indikator yang diuji dan di ukur untuk menganalisa perbandingan pembangunan desa sebelum dan sesudah implementasi dana desa di kabupaten Nagan Raya.

Oleh karena itu, untuk mengetahui dampak program Dana Desa terhadap peningkatan ekonomi yang meliputi pendapatan masyarakat diperlukan sebuah analisa ilmiah untuk mengetahui efektivitas pemanfaatan dana desa dalam mengentaskan kemiskinan di Kecamatan kuala kabupaten Nagan Raya provinsi Aceh.

\section{LANDASAN TEORETIS}

\section{Pemanfaatan Dana Desa}

Alokasi Dana Desa (ADD) adalah dalam rangka meningkat pemberdayaan, kesejahteraan dan pemerataan pembangunan dipedesaan melalui dana APBD kabupaten, provinsi dan pemerintah pusat, pemerintah kabupaten, provinsi dan pusat perlu merealisasikan dana APBD masing masing sebesar $10 \%$ untuk dana Alokasi Dana Desa (ADD) (Ramly, 2019). Peraturan Daerah Nomor 14 Tahun 2008 tentang Alokasi Dana Desa (ADD) yang metetapkan pemanfaatan ADD mengacu pada Peraturan Pemerintah Nomor 72 Tahun 2005 tentang Desa. 
pemanfaatan ADD ini harus sejalan dengan tujuan program Nawacita Indonesia, salah satunya mewujudkan desa yang mandiri.

Desa mandiri merupakan tujaun dari program kemandirian desa dalam Pemberdayaan masyarakat desa melalui program program penyelenggaraan pemerintahan dan pembangunan di tingkat desa, secara substansial ruang dari Ungernsi pelaksanan ADD sangat didukungan dari dana yang diserahkan, maka desa dapat menyelenggarakan pemerintahan dan pelaksanaan pembangunan dalam kapasitas kewenangan yang dimiliki, disamping menerima program-program pembangunan dari Pemerintah, Pemerintah Provinsi maupun Pemerintah Kabupaten/Kota (Diansari, 2015), sehingga dapat menghasilkan desa kemandirian dan kesejahteraan masyarakat dengan meningkatkan pengetahuan, sikap, keterampilan, perilaku, kemampuan, kesadaran, serta memanfaatkan sumber daya melalui penetapan kebijakan, program, kegiatan, dan pendampingan yang sesuai dengan esensi masalah dan prioritas kebutuhan masyarakat desa (Takaliuang, Tulusan dan Sondakh, 2015).

Pembahasan kegiatan pembangunan di tingkat desa harus berpedoman pada prinsip-prinsip Perencanaan Pembangunan Partisipasi Masyarakat Desa (P3MD). Prinsip tersebut mengharuskan keterlibatan masyarakat dalam pengambilan keputusan dan menentukan pembangunan yang akan dilaksanakan khususnya yang berlokasi di desa yang bersangkutan (Takaliuang, Tulusan dan Sondakh, 2015).

Pembangunan dapat diartikan suatu usaha perubahan untuk menujukeadaan lebih baik berdasarkan kepada norma-norma tertentu, perencanaan pemberdayagunaan potensi alam, manusia dan sosial budaya inilah yang disebut dengan pembangunan. Sedangkan Pemberdayaan masyarakat mempunyai arti meningkatkan kemampuan atau meningkatkan kemandirian masyarakat. Pemberdayaan masyarakat bukan hanya meliputi penguatan individ tetapi juga pranata-pranata sosialnya (Karubaba, Purwanti, dan Susanto, 2014).

Konsep Pendekatan dalam pembangunan yang berorientasi pada masyarakat, harus diubah dengan pendekatan pembangunan yang berpusat pada masyarakat. Artinya usaha perubahan yang berlangsung dalam masyarakat dan pendekatan pembangunan berorientasi pada masyarakat perlu diubah sebagai figur sentral pembangunan dengan dimensi (Wahyudin, 2020). Salah satunya adalah 
konsep perubahan sosial yang menuju kearah perkembangan dan kemajuan dan memerlukan masukan-masukan yang menyeluruh dan berkesimbungan dan merupakan usaha yang dilakukan oleh pemerintah dan masyarakat untuk mencapai tujuan negara (Haryono, 2012).

Tujuannya bukan hanya pemberdayaan masyarakat secara pembangunan dan ekonomi melainkan upaya melegetimasi dan memperkokoh segala bentuk gerakan masyarakat yang ada, gerakan kesejahteraan mandiri masyarakat dengan ujung tombak LSM, gerakan protes masyarakat terhadap dominasi dan intervensi birokrasi negara, kesewenangan dunia industri, gerakan moral, yang bermaksud memberikan baju moral kekuatan (force) yang menjadi andalan hubungan sosial dan tiga dekade terakhir upaya pemberdayaan rakyat mencakup yaitu, (1) Pendampingan yang dapat menggerakkan partisipasi total masyarakat, (2) Penyuluhan dapat merespon dan membantu perubahan-perubahan yang terjadi di masyarakat dan (3) Pelayanan yang berfungsi sebagai pengendali ketepatan distribusi aset sumberdaya fisik dan non fisik yang diperlukan oleh masyarakat (wahyuddin, ddk, 2019).

Pembangunan merupakan upaya yang terus menerus yang dilakukan dengan tujuan menempatkan manusia pada posisi dan perannya secara wajar sebagai subjek dan objek pembangunan untuk mampu mengembangkan dan memberdayakan dirinya sehingga keluar dapat berhubungan dengan serasi dan dinamis, sedangkan keluar dapat menciptakan keseimbangan. Sedangkan Pemberdayaan masyarakat merupakan upaya pemerintah untuk mendorong akselerasi penurunan angka kemiskinan yang berbasis partisipasi yang diharapkan dapat menciptakan proses penguatan sosial yang dapat mengantar masyarakat miskin menuju masyarakat yang madani, sejahtera, berkeadilan serta berlandaskan iman dan takwa (Gunawan, 2009).

Kemiskinan dan pemerataan memiliki pengertian yang multidimensi, yaitu (1) ekonomi, dimana terdapat ketiadaan pendapatan, nutrisi, rumah dan pakaian; (2) sosial, dimana hubungan sosial, keterasingan dan ketidakamanan; (3) politik disebabkan oleh ketidak berdayaan dan tidak tersedianya politik; (4) budaya, yang berakibat rendahnya rasa sebagai imbas dari tingkat pendidikan dan tingkat melek rendah (Yenida, 2016).

Menurut Ananda dalam Suhandoyo (2002:182), tujuan pembangunan pada masa lalu adalah pertumbuhan (growth) dan sekalilagi pertumbuhan. Seharusnya 
pertumbuhan hanya bersifat indikator pembangunan bukan tujuan. Tujuan pembangunan itu adalah meningkatkan kualitas hidup manusia. Beberapa indikator pembangunan bisa kita susun sebagai berikut : Partisipasi (participation), keadilan sosial (sosial justice), kesempatan kerja untuk semua (work for all), dan kemandirian (autonomy). Demi mencapai kebutuhan yang diinginkan oleh individu, kelompok, dan masyarakat agar mereka memiliki kemampuan untuk memilih dan mengontrol lingkungannya untuk mampu memenuhi keinginan, termasuk juga akses terhadap sumberdaya yang dimiliki (Sriwahyuni, 2015).

\section{Efektivitas Peningkatan Ekonomi Melalui Dana Desa}

Pemanfaatan Dana Desa melalui program Pemberdayaan Masyarakat antara lain (BPKP, 2015). Pelatihan usaha ekonomi, pertanian, perikanan dan perdagangan, Pelatihan teknologi tepat guna, Pendidikan, pelatihan, dan penyuluhan bagi kepala desa, perangkat desa, dan Badan Pemusyawaratan Desa, Peningkatan kapasitas masyarakat.

Pemanfaatan dana desa ini diharapkan berjalan sempurna sesuai targettarget yang ditentukan oleh pemerintah. Oleh karenanya ada beberapa prioritas yang dijadikan ukuran dalam penggunaan dana desa seperti prioritas dasar yang tertuang dalam APBDes yaitu prioritas penggunaan dana desa pada bidang penyelenggaraan pemerintahan desa, prioritas pada bidang pembangunan desa, bidang pemberdayaan masyarakat desa, dan pada bidang pembinaan masyarakat desa. sehingga dengan adanya beberapa prioritas yang dilakukan dalam pemanfaatan dana desa tentunya dapat kita lakukan monitoring dan evaluasi sejauhmana penggunaan dana desa berdampak pada setiap bidang yang dituangkan dalam APBDes.

Dalam Ramly, dkk, (2018). Mendefinisikan efektivitas sebagai istilah yang diungkapkan dengan cara berbeda oleh orang-orang yang berbeda pula. Namun menurut Chung \& Megginson yang disebut dengan efektivitas ialah kemampuan atau tingkat pencapaian tujuan dan kemampuan menyesuaikan diri dengan lingkungan agar organisasi tetap survive (hidup). Efektivitas merupakan kriteria evaluasi yang dapat diukur bilamana suatu kebijakan program dapat mencapai hasil (efek) dan memberi pengaruh yang diinginkan (Asfi dan Wijaya, 2015). 
Menurut Drucker efektivitas didefinisikan sebagai melakukan pekerjaan yang benar (doing the raight things), sedangkan efisien adalah melakukan pekerjaan dengan benar (doing things right) Efektivitas selalu terkait dengan hubungan antara hasil yang diharapkan dengan hasil sesungguhnya dicapai (Asfi dan Wijaya, 2015).

Secara umumnya pengertian efektifitas menunjukkan pada taraf tercapainya hasil, sering atau senantiasa dikaitkan dengan pengertian efisien, meskipun sebenarnya ada perbedaan diantara keduanya. Efektifitas menekankan pada hasil yang dicapai, sedangkan efisiensi lebih melihat pada bagaimana cara mencapai hasil yang dicapai itu dengan membandingkan antara input dan outputnya.

Dalam kasus ini penulis akan mengkaji pemanfaatan dana desa yang dilakukan masyarakat dengan melakukan observasi terbuka dan penilaian objektif terhadap arah penggunaan dana desa yang di lihat melalui efektifitas penggunaannya. Dengan demikian pemberian dana desa ini dapat dinikmati dan berdampak positif bagi masyarakat. Begitu juga dengan target yang dilakukan oleh pemerintah dengan adanya program pengentasan kemiskinan ini.

Berdasarkan pembahasan tersebut, maka hipotesis penelitian ini adalah:

$\mathrm{H}_{1}$ : Efektifitas Dana Desa berpengaruh terhadap pengurangan kemiskinan di Kecamatan Kuala Kabupaten Nagan Raya

$\mathrm{H}_{0}$ : Efektifitas Dana Desa Tidak Berpengaruh Terhadap Pengurangan Kemiskinan di Kecamatan Kuala Kabupatem Nagan Raya.

\section{METODE}

Lokasi penelitian ini berada di Kecamatan Kuala Kabupaten Nagan Raya, dengan populasi desa berjumlah 17 desa yang ada di Kecamatan kuala. Namun sampel yang diambil ialah sebanyak 10 desa, terdiri atas desa Blang Bintang, Kuta Makmue, Ujong Patihah, Ujong Sikuneng, Ujong Padang, Jogja, Simpang Peut, Lawa Batu, Alue Ie Mameh, Puloe Ie dan Blang Muko. Sedangkan sumber data berasal dari data primer dan data sekunder. Data primer diperoleh dengan menemui langsung objek yang diteliti, sedangkan data sekunder diperoleh melalui sumber lain dari internet, dokumentasi, jurnal dan mengakses data dari badan pusat statistik (BPS) dan Badan Pemberdayaan Masyarakat (BPM) Kabupaten Nagan Raya yang terkait penelitian yang diteliti. 
Teknik pengumpulan data ditempuh dengan cara observasi, wawancara, dan kuesioner. Observasi dilakukan terhadap desa yang menjadi sampel penelitian dengan melihat dan mengamati obejek secara langsung terkait Efektivitas pemanfaatan Dana Desa Terhadap Pengentasan Kemiskinan di beberapa desa. Kemudian wawancara dilakukan langsung dengan aparat desa yang menjadi sampel, terdiri atas kepala desa, sekretaris desa, bendahara desa, dan Masyarakat.

Analisa Penelitian ini menggunakan metode data panel (pooled panel data) dengan Random Effect Model. Data yang digunakan terdiri atas data cross section dan time series dengan jumlah individu yang beragam dan hanya diambil dalam kurun waktu 4 tahun. seperti penelitian sebelumnya Dura (2016), Azwardi \& Sukanto (2014), menggunakan regresi berganda, Sari \& Abdullah (2017) Menggunakan analisa Fixed Effect Model (FEM). Namun penelitian ini mecoba melihat model terbaik terhadap perilaku Dana Desa di kecamatan Kuala. Sesuai penelitian Fajriah \& Rahayu (2016) yang menggunakan regresi data panel dengan analisa Random Effect Model (REM). Penentuan dan pemilihan model terbaik dalam model regresi data panel penulis melakukan estimasi statistik antara FEM dan REM dengan melakukan Uji Hausman (Hausman test).

Adapun model regresi dalam bentuk masing-masing variabel respon adalah sebagai berikut:

$\operatorname{LogPoverty}\left(Y_{i t}\right)=\beta_{0}+\beta_{1} \operatorname{Logdd}_{1}+\beta_{2} \operatorname{adg}_{2}+\log D_{i}+e_{i} \ldots \ldots \ldots \ldots$

Dimana;

Log Poverty adalah prosentase tingkat kemiskinan di kecamatan Kuala Kabupaten nagan raya.

Logdd adalah Dana Desa yang diterima setiap desa di kecamatan kuala bersumber dari APBN

Logadg adalah Alokasi dana desa yang diterima oleh desa dikecamatan kuala bersumber dari APBK

$\log D_{i}$ adalah variabel dummy.

Dalam persamaan di atas juga dimasukkan variabel dummy berupa tahun penelitian dengan tujuan untuk mengetahui ada tidaknya perubahan kemiskinan desa pada Tahun 2015 hingga 2018. Sedangkan pada pemilihan model terbaik antara FEM dan REM mengunakan Uji Hausman sebagai berikut:

$$
m=\wedge \mathrm{q}^{\prime} \operatorname{var}(\mathrm{q})^{-1 \mathrm{q}}
$$




$$
\operatorname{dimana} \mathrm{q}^{\wedge}=\left[\beta_{\mathrm{OLS}}-\beta_{\mathrm{GLS}}\right] \text { dan } \operatorname{var}(\mathrm{q})=\operatorname{var}\left(\beta_{\mathrm{OLS})}-\operatorname{var}\left(\beta_{\mathrm{GLS}}\right)\right.
$$

Statistik Uji Hausman mengikuti distribusi statistik chi square dengan degree of freedom sebanyak $k$ dimana $k$ adalah jumlah variabel independen. Jika kita menolak hipotesis nol yaitu ketika nilai statistik hausman lebih besar dari nilai kritisnya maka model yang tepat adalah model fixed effect sedangkan apabila kita gagal menolak hipotesis nol yaitu ketika nilai statistik hausman lebih kecil dari nilai kritisnya maka model yang tepat adalah model random effect (Widarjono, 2013). Uji spesifikasi Hausman membandingkan model efek tetap dan model efek acak. Jika hipotesis nol yang menyatakan tidak ada korelasi antara efek individu dengan regresor tidak di tolak, model efek random disarankan daripada efek tetap (Susanti, 2013).

Operasional variabel yang digunakan ialah variabel independen ialah DD (dana desa), dan alokasi dana gampong (ADG). Sedangkan variabel dependen menggunakan rasio kemsikinan (Poverty) di Kecamatan Kuala Kuala Kabupaten Nagan Raya. Variabel Dana Desa dan Alokasi Dana Desa dikumpulkan sejak tahun 2015 sampai Tahun 2018 dengan jumlah sampel sebanyak 10 desa. Sedangkan Variabel kemiskinan (Poverty) dikumpulkan melalui data BPS sejumlah prosentase di kecamatan kuala selama kurun waktu 4 tahun.

Tabel 1.1 Variabel Dependen, Variabel Independen dan Satuan

\begin{tabular}{cccc}
\hline No & Variabel & Keterangan & Satuan \\
\hline $\mathbf{1}$ & Poverty (Y) & Prosentase Penduduk miskin Kecamatan Kuala & Persen \\
\hline $\mathbf{2}$ & DD (X1) & Dana Desa yang diterima setiap desa dari & Jutaan Rupiah \\
& & APBN & \\
\hline $\mathbf{3}$ & ADG (X2) & Alokasi dana Desa yang diterima setiap desa & Jutaan Rupiah \\
& & dari APBK & \\
\hline
\end{tabular}

Penelitian ini menggunakan Data Panel Seimbang (Balance Panel Data), terdiri dari data Time Series dari tahun 2015 hingga tahun 2018 dan data Cross Section terdiri dari 10 desa dalam kecamatan kuala dengan kode BB, KTM, UJS, UPD, JOG, SP4, LWT, BM, AIM, dan PI, sehingga observasi yang digunakan dalam penelitian ini adalah 30 unit. 


\section{HASIL DAN PEMBAHASAN}

\section{Kemiskinan Desa di Kecamatan Kuala}

Berdasarkan data Badan Pusat Statstik, jumlah penduduk di kecamatan Kuala pada Tahun 2015 berjumlah 20.593 jiwa. Jumlah ini terdiri dari 10.433 penduduk laki-laki dan 10.160 penduduk perempuan. Rasio Jenis kelamin (Sex Ratio) di kecamatan Kuala adalah 103. Hal ini berarti setiap 100 penduduk perempuan terdapat 103 penduduk laki-laki di kecamatan Kuala (BPS, 2016).

Tabel 1.3 Indikator Kemiskinan Kecamatan Kuala

\begin{tabular}{ccccc}
\hline \multicolumn{1}{c}{ Uraian } & Satuan & $\mathbf{2 0 1 5}$ & $\mathbf{2 0 1 6}$ & $\mathbf{2 0 1 7}$ \\
\hline $\begin{array}{c}\text { Garis } \\
\text { Kemiskinan }\end{array}$ & Rp & 361,359 & 374,236 & 400,811 \\
\hline $\begin{array}{c}\text { Jumlah } \\
\text { Penduduk } \\
\text { Miskin }\end{array}$ & Jiwa & 31.320 & 30.310 & 31.060 \\
Persentase & $\%$ & & & \\
Penduduk & & & & \\
Miskin & & & & \\
\hline
\end{tabular}

Sumber: BPS Nagan Raya 2017

Persentase penduduk miskin di kecamatan kuala mengalami fluktuasi, dari keterangan Tabel di atas dapat kita lihat dari Tahum 2015 sebesar $20.13 \%$ penduduk miskin di kecamatan kuala, kemudian turun sebesar $19.25 \%$ pada tahun 2016 dan meningkat kembali pada tahun 2017 sebesar 19.34 persen dengan perbedaan rasio 9 persen.

\section{Penggunaan Dana Desa terhadap Kemiskinan}

Penggunaan dana desa di kecamatan kuala berawal dari tahun 2015 hingga sekarang, Untuk menganalisa apakaha dana desa berpengaruh terhadap kemiskinan atau dengan adanya dana desa tingkat kemiskinan di desa dapat di atasi. Penulis telah memasukkan 10 sampel desa dari 17 desa dengan penentuan Sample Purposive sampling. Artinya penentuan sampel ini melihat karakteristik desa dengan pemanfaatan dana desa secara aturan yang ditentukan oleh 
pemerintah dan desa yang belum mampu secara administratif mengelola dana desa. Untuk itu sebelum melakukan pengujian sampel dengan menggunakan estimasi regresi data panel ada dua model analisa yang harus ditempuh untuk melihat yang mana model analisa terbaik yang digunakan antara efek tetap dan efek random. Oleh karenanya harus di uji dahulu spesifikasi statistik melalui Hausmann Test (Uji Hausman) sebagai berikut.

Tabel 1.4 Hausman Test (Uji Hausman)

Correlated Random Effects - Hausman Test

Pool: DD

Test cross-section random effects

Chi-Sq.

Test Summary Statistic Chi-Sq. d.f. Prob.

\begin{tabular}{llll}
\hline \hline Cross-section random & 1.403647 & 2 & 0.4957
\end{tabular}

Sumber: Hasil Data Diolah Dari Eviews 8.0

Setelah Melakukan uji hausman dengan p-value sebesar 0.000 sedangkan nilai kritis chi squares dengan df sebesar 2 pada $\alpha=5 \%$, Sehingga diputuskan untuk menolak H0. Maka diputuskan model Random Effect lebih cocok dibandingkan model lainnya, karena degree of freedom-nya lebih minim.

Tabel 1.5 Hasil Regresi Random Effect Model (REM)

Dependent Variable: LOG(POVERTY?)

Method: Pooled EGLS (Cross-section random effects)

Date: 03/31/18 Time: 09:53

Sample (adjusted): 20152017

Included observations: 3 after adjustments

Cross-sections included: 10

Total pool (balanced) observations: 30

Swamy and Arora estimator of component variances 


\begin{tabular}{ccccc} 
Variable & Coefficient & Std. Error & t-Statistic & Prob. \\
\hline \hline C & 3.051245 & 0.017614 & 173.2333 & 0.0000 \\
LOG(DD?) & 0.018245 & 0.001331 & 13.70604 & 0.0000 \\
LOG(ADG?) & -0.023943 & 0.000509 & -47.02649 & 0.0000 \\
Random Effects & & & & \\
(Cross) & & & & \\
_BB-C & 0.000000 & & & \\
_KTM-C & 0.000000 & & & \\
_UJS-C & 0.000000 & & & \\
_UPD-C & 0.000000 & & \\
_JOG-C & 0.000000 & & \\
_SP4-C & 0.000000 & & \\
_LWT-C & 0.000000 & & \\
_BM-C & 0.000000 & & \\
_AIM-C & 0.000000 & & \\
_PI-C & 0.000000 & & \\
\hline \hline SH - & & & \\
\hline
\end{tabular}

Sumber: Hasil Data Diolah Dari Eviews 8.0

Hasil analisa di atas menunjukkan variabel dana desa dan alokasi dana gampong memiliki hubungan signifikan dengan p-value sebesar 0.0000, dengan asumsi sig-tailed sebesar $\alpha=0.05$, yaitu lebih kecil sehingga dapat dikatakan variabel dana desa dan alokasi dana gampong berpengaruh positif dan signifikan terhadap perilaku kemiskinan. pemilihan data variabel terhitung sejak 2015 sampai dengan 2018, dengan memasukkan variabel dummy.

Terlihat pada tabel hasil regresi di atas dari 10 sample yang digunakan, dapat kita interprestasi penggunaan dana desa terhadap pengentasan kemiskinan berpengaruh positif signifikan. Seperti gampong BB, KTM, UJS, UPD, JOG, SP4, LWT, BM, AIM, dan PI dengan nilai probabilitas 0.00, pada asumsi sig-tailed lebih kecil $\alpha=0.05$.

Variabel Dana Desa berpengaruh Positif dan signifikan terhadap kemiskinan desa. Koefisien sebesar 0,01 ini memberikan indikasi jika setiap penambahan 1\% Alokasi Dana Desa, maka akan menurunkan kemiskinan desa sebesar 0,01\%. Dimana nilai tersebut sesuai dengan hipotesis bahwa jika Dana Desa naik maka akan menurunkan kemiskinan desa. Kemudian variabel Alokasi 
Dana gampong berpengaruh negatif dan signifikan terhadap kemiskinan desa. Koefisien sebesar -0,02, memberikan indikasi jika setiap penambahan 1\% Alokasi Dana Gampong, maka akan menurunkan kemiskinan desa sebesar 0,02\%. Dimana nilai tersebut sesuai dengan hipotesis bahwa jika Alokasi dana Gampong naik maka akan menurunkan kemiskinan desa.

Hasil penelitian sesuai dengan penelitian sebelumnya, seperti penelitian Sari \& Abdullah (2017), Dura (2016), dan Azwardi \& Sukanto (2014). Menyatakan bahwa dana desa berpengaruh signifikan terhadap kemiskinan. Pertama Probabilitas t hitung variabel Dana Desa $=0,0000=$ nilai probabilitas $\alpha=$ 5\% maka Ho ditolak dan H1 diterima yang artinya variabel Dana Desa (DD) berpengaruh signifikan terhadap kemiskinan desa.

Kedua, Probabilitas t hitung sebesar $0,0000=$ nilai probabilitas $\mathrm{a}=5 \%$ maka Ho ditolak dan H1 diterima yang artinya variabel Alokasi Dana Gampong (ADG) berpengaruh signifikan terhadap kemiskinan desa. Maka hasil Uji regresi variabel DD dan ADG dapat di simpulkan bahwa dana desa berpengaruh terhadap kemiskinan di kecamatan Kuala Kabupaten Nagan Raya.

Pemberdayaan masyarakat melalui Potensi desa sangat penting dalam mewujudkan desa yang sejahtera. Selain itu potensi desa ini merupakan tolak ukur pengalokasian dana desa yang ada diseluruh indonesia selain jumlah penduduk, angka kemiskinan, luas wilayah desa, dan tingkat kesulitan geografi desa yang digunakan saat ini dalam formula dana desa (DD).

Hasil potensi desa (Podes) diukur oleh badan pusat statistik. Data potensi desa merupakan sumber data tematik berbasis luas wilayah yang mampu menggambarkan potensi yang dimiliki oleh setiap wilayah di Indonesia. Data potensi desa dilaksanakan setiap empat tahun sekali yang telah dilaksanakan pada tahun 2014 dan kembali dilaksanakan pada tahun 2018 mendatang (Team KOMPAK, 2017).

Oleh karena itu diperlukan peran dan fungsi desa dalam mengelola potensi desa baik secara fisik maupun non-fisik. Desa melalui sistem pemerintahannya memiliki peran yang besar dalam memanfaatkan potensi yang ada di desa atau wilayah hukum masing-masing potensi desa dan mengatur dan mengurus kepentingan masyarakat bedasarkan prakarsa masyarakat, hak asal-usul dan/atau hak istiadat sesua dengan undang-undang desa. Kemudian dalam mengukur dan 
melihat potensi desa, tentu terdapat beberapa cara diantaranya dengan melihat sumber daya alam yang dimiliki atau kegiatan ekonomi yang dilakukan masyarakat setempat.

Di Indonesia melalui undang-undang No 6 Tahun 2014 tentang desa yang memberikan wewenang otonomi desa walaupun hanya sebagai pelengkap dari otonomi daerah secara normatif (Aziz, 2016). Kemudian di dukung oleh peraturan pemerintah nomor 72 tahun 2005, yang menyatakan bahwa untuk meningkatkan pendapatan desa pemerintah desa boleh mendirikan badan usaha milik desa sebagai alternatif pengelolaan sumber ekonomi bagi masyarakat untuk mengekplorasi potensi desa (Hardjiono, dkk, 2014).

Ada tiga hal utama dalam fase pembangunan yang dapat menjadi misi pemerintahan gampong dalam pembangunan yaitu pertama, meningkatkan kualitas hidup manusia, kedua meningkatkan kesejahteraan masyarakat gampong, dan ketiga, menanggulangi kemiskinan. Kemudian pada fase pemberdayaan sudah seharusnya diutamakan kepada peningkatan kesejahteraan masyarakat gampong, hal ini sesuai dengan filosofi pembangunan desa yang dituangkan dalam undangundang nomor 6 Tahun 2014 tentang desa, setiap kegiatan dan program yang disusun oleh pemerintah gampong melalui musrenbang dan dituangkan kedalam APBG semestinya diarahkan setidanya kedalam dua hal yaitu Pengentasan Kemiskinan dan pemberdayaan masyarakat. Sehingga pemerintah gampong saat ini memiliki kewenangan atau otonomi dalam mengatur pemerintahan gampongnya sendiri.

Oleh karena itu dari hasil penelitian ini dapat kita lihat perilaku pemanfaatan dana desa sangat berpotensi besar untuk meningkatkan kesejahteraan masyarakat dan mengurangi angka kemiskinan di desa. hasil regresi menunjukkan bahwa perilaku dana desa dan alokasi dana desa mampu dan berpengaruh untuk meningkatkan kesejahteraan hidup masyarakat yang ada di desa. tentunya ini perlu di dukung oleh beberapa pihak agar prioritas pembangunan di arahkan kepada skala kebutuhan dan kemampuan desa sendiri. kemudian pemberdayaan masyarakat ini dapat dilakukan oleh pemerintah desa melalui program-program yang bermanfaat dan di musyawarahkan dengan masyarakat, sehingga masyarakat pula terlibat aktif dalam ruang pembangunan di desa.

\section{SIMPULAN}


Dari pembahasan di atas maka dapat kita peroleh beberapa temuan dari kajian diatas yaitu; pertama efektifitas penggunaan dana desa di kecamatan kuala masih belum begitu efektif secara akumulatif di kuala. Secara statistik angka kemsikinan di kecamatan kuala masih mengalami kenaikan walaupun ditemukan pada tahun 2016 prosentasenya rendah, akan tetapi meningkat 9 persen pada tahun 2017. Hal ini menunjukkan bahwa masih terdapat permasalahan yang serius dalam pengelolaan dana desa pada tahun 2015 hingga 2017. Kemudian dari hasil regresi model random effect dapat disimpulkan bahwa variabel dana desa berpengaruh positif dan signifikan terhadap kemisikinan dengan Probabilitas sebesar 0,0000 = p-value $\alpha=5 \%$. Kemudian variabel alokasi dana desa berpengaruh negatif signifikan terhadap kemiskinan dengan Probabilitas sebesar $0,0000=$ p-value $\alpha=$ $5 \%$. Artinya dengan menambahkan $1 \%$ dana desa atau meningkatkan dana desa akan mengurangi kemiskinan di Kecamatan Kuala Kabupaten Nagan Raya.

Keterbatasan dalam penelitian ini hanya menggunakan data dari responden hanya sebanyak sepuluh desa dan tidak menggunakan data laporan tahunan desa yang berjalan. Maka saran untuk peneliti selanjutnya dengan menambah data pendukung laporan tahunan desa agar lebih akurat dalam meneliti terutama mengenai kesejahteraan masyarakat.

\section{PUSTAKA ACUAN}

Asfi, U. \& Wijaya, H.B. Efektivitas Pemberdayaan Masyarakat Dalam Pengentasan Kemiskinan Pada Program Gerdu Kempling Di Kelurahan Kemijen Kota Semarang” Jurnal Teknik PWK. Volume 4 Nomor 2 tahun 2015. Online : Http://Ejournal S1.Undip.Ac.Id/Index.Php/Pwk.

Aziz, N.L.L.The Village Autonomy An The Effectiveness Of Village Fund. Jurnal Penelitian Politik. Volume 13. No 2. Tahun 2016

Azwardi \& Sukanto. Efektifitas Alokasi dana desa (ADD) dan Kemiskinan di provinsi sumatra selatan. Jurnal Ekonomi Pembangunan, Journal Of Economic And Development. Vol 12 No 1 hal:29-41 Tahun 2014.

Badan Pengawasan Keuangan Dan Pembangunan (BPKP). (2015). Petunjuk Pelaksanaan Bimbingan \& Konsultasi Pengelolaan Keuangan Desa, Deputi Bidang Pengawasan Penyelenggaraan Keuangan Daerah, (Jakarta: Buku Bantu Berdasarkan Undang-Undang Nomor 6 Tahun 2014 Tentang Desa Pengelolaan Pembangunan Desa).

BPS Nagan Raya. (2016). Statistik Kecamatan Kuala 2016, Badan Pusat Statistik Kabupaten Nagan Raya. 
Diansari, R.E. Analisa Implementasi Alokasi Dana Desa (ADD) Kasus Seluruh Desa Di Kecamatan Kledung Kabupaten Temanggung Tahun 2013, Seminar Nasional Universitas PGRI Yogyakarta Tahun 2015.

Dura, J. Pengaruh Akuntabilitas Pengelolaan Keuangan Alokasi Dana Desa, Kebijakan Dana Desa, Dan Kelembagaan Desa Terhadap Kesejahteraan Masyarakat (Studi Kasus Pada Desa Gubugklakah Kecamatan Poncokusumo Kabupaten Malang). Jurnal JIBEKA, Vol 10 No 1 Hal:2632, Tahun 2016.

Fajriah, N \& Rahayu, S.P. Pemodelan Faktor-Faktor Yang Mempengaruhi Kemiskinan Kabupaten/Kota Di Jawa Timur Menggunakan Regresi Data Penel. Jurnal Sains dan Seni ITS. Vol 5. No 1 2337-3520 (2301-928 X Print) Tahun 2016.

Gunawan., S. 2009. Mewujudkan Kesejahteraan Bangsa: Menanggulangi Angka Kemiskinan Dengan Prinsip Pemberdayaan Masyarakat. (Jakarta: PT Elex Media Komputindo).

Hardijono, R. dkk. Economic Independence Of The Village Through Institutional Village Enterprise (BUMDes). IOSR Journal of economic and finance (IOSR-JEF), Volume 3, Issue 2, Maret-April 2014

Haryono, S. (2012). Buku Pengantar Studi Administrasi Pembangunan. (Bandung: Mandar Maju).

Karubaba, O. Purwanti, F. dan Suprapto, D. Evaluasi Program Pemberdayaan Masyarakat Pesisir Di Desa Sarawandori, Kosiwo Kabupaten Kepulauan Yapen, Provinsi Papua (Evaluation Of Coastal Community Empowerment Program In The Sarawandori Village Kosiwo Yapen Island Regency, Papua Province), Diponegoro Journal Of Maquares Management Of Aquatic Resources, Volume 3, Nomor 4, Halaman 119-124, Tahun 2014.

Ramly, A. R., Wahyuddin, W., Mursyida, J., \& Mawardati, M. (2019). Analysis Of Village Building Index In Village Development In Kuala SubDistrict. Jurnal Ekonomi Pembangunan, 17(1), 22-31.

Ramly, A., Wahyuddin, W., Mursyida, J., \& Mawardati, M. (2018). The Implementation of Village Fund Policy in Improving Economy of Village Society. Jurnal Ilmiah Peuradeun, 6(3), 459-478.

Sari, I.M. \& Abdullah, M.F. Analisis Ekonomi Kebijakan Dana Desa Terhadap Kemiskinan Desa Di Kabupaten Tulungagung. Jurnal ekonomi Pembangunan. Vol 15 No.1 Juni Tahun 2017.

Sriwahyuni, A. (2015). Hubungan Tingkat Partisipasi Masyarakat Dan Efektivitas Kegiatan Simpan Pinjam Perempuprogram Nasional Pemberdayaan Masyarakat (SPP PNPM) Mandiri di Desa Talagasari, Kecamatan Kadungora,Kabupaten Garut, Skripsi tidak dipublikasikan, Institut Pertanian Bogor 
Sumaryadi, N. (2005). Efektivitas Implementasi Kebijakan Otonomi Daerah. (Jakarta: Citra Utama).

Susanti, S. Pengaruh Produk Domestik Regional Bruto, Pengangguran Dan Indeks Pembangunan Manusia Terhadap Kemiskinan Di Jawa Barat Menggunakan Analisis Data Panel. Jurnal Matematika Integratif. Vol 9 No 1 p:1-18 Tahun 2013.

Takaliuang, R.A, Tulusan, F. dan Sondakh, T. Pemanfaatan Alokasi Dana Desa (Add) Dalam Pembangunan Desa Di Desa Tanjung Sidupa Kecamatan Pinogaluman Kabupaten Bolaang Mongondow Utara”. Jurnal Administrasi Publik UNSRAT. Vol 4 No 32, Tahun 2015

Tangkumahat, F. V., Panelewen, V. V., \& Mirah, A. D. (2017). Dampak Program Dana Desa Terhadap Peningkatan Pembangunan Dan Ekonomi Di Kecamatan Pineleng Kabupaten Minahas. Agri-Sosioekonomi, 13(2A), 335-342.

Team KOMPAK. Policy Analysis Village Fund and Poverty Allevation. Jakarta: Australian-Indonesian Government Patnership, 2017.

Wahyuddin, W., Ramly, A., Djalil, M. A., \& Indriani, M. (2019). Efektivitas Pemanfaatan Dana Desa dalam Mengentaskan Kemiskinan di Kec Kuala Kabupaten Nagan Raya. NUANSA: Jurnal Penelitian Ilmu Sosial dan Keagamaan Islam, 16(2), 181-193.

Wahyuddin, W., Ramly, A., Djalil, M. A., \& Indriani, M. (2020). Utilization Of Local Potentials, Financial Capital, Human Resources, And Community Participation In Forming Village-Owned Enterprise (Bumdes) In Nagan Raya District. JEM Jurnal Ekonomi dan Manajemen, 6(1), 27-37.

Widarjono, A. (2013). Ekonometrika Pengantar Dan Aplikasinya, (Yogyakarta: UPP STIM YKPN).

Yenida, E.S. Efektifitas Program Pemberdayaan Ekonomi Masyarakat Miskin Diwilayah Pesisir Pantai Sumatera Barat. National Conference Of Applied Sciences, Engineering, Business And Information Technology. Politeknik Negeri Padang, 15 - 16 Oktober 2016. 